\title{
Construction of Chinese Coal Enterprises' Ethic System
}

\author{
Gang Liu ${ }^{a}$, Yufeng Sun ${ }^{b}$, Zhangliang Chen ${ }^{c}$, Junwei Shi ${ }^{d}$, Lifeng Li e, Shuhu \\ Feng ${ }^{f}$, Guibing Li ${ }^{g}$ \\ Shandong Institute of Business and Technology, Yantai 264005, China \\ aliugang7912@163.com, bsyfeng2004@tom.com, cchenzhl_yt@126.com, d542670686@qq.com, \\ e540367846@qq.com, 'fengshuhu@sdibt.edu.cn, gliguibing@zju.edu.cn
}

Keywords: coal enterprise; safety; enterprise ethic; social responsibility.

\begin{abstract}
Enterprise ethic relationships include relationships between enterprises and investors, employees, customers, upstream and downstream partners, competitors, government, media, ecological environment, etc. As a kind of special enterprise, coal enterprise ethical system plays a very important part in aspects of maintaining normal operation of enterprises, guaranteeing production safety of coal mine and so on. Ethic anomie behaviors of Chinese coal enterprises increase day by day, therefore coal enterprises should construct their own ethic system in aspects of state-business, employees, ecology, social responsibility, etc.
\end{abstract}

\section{Introduction}

Ethic refers to a kind of standard and specification which is formed in accordance with things' respective characteristics in the process of interaction. Enterprise ethic, also known as business ethic, refers to a summation of ethic relation, ethic consciousness, ethic code and ethical activities contained in enterprise production, operation, management and life. Enterprise ethic which is core of the enterprise values reflects the value judgment of "good and evil". In the operation and management activities, an enterprise can truly achieve the ideal state of management and make the enterprise possess strong competitiveness only on the condition of valuing and strengthening enterprise ethic construction and strictly following the enterprise ethic. With the deepening of the reform and opening up, the enterprise is becoming more and more away from the government and becoming an independent market main body, meanwhile the anomie behavior of enterprise operation is increasingly revealed. Some market main bodies pursue benefit maximization by hook or by crook, so misconduct and moral hazards behaviors occur frequently, which not only affect people's life greatly, but also seriously interfere with the market economic orders and these also cause common concern of economic ethic, especially the enterprises ethical issues of the whole society. As a kind of special enterprise, coal enterprise ethic system plays an important part in maintaining the normal operation order, guaranteeing coal mine safety production, etc.

\section{Connotation of Enterprise Ethic}

Enterprise ethic relationships include relationships between enterprises and investors (shareholders), employees, customers, upstream and downstream partners, competitors, government, media, ecological environment, etc.

Shareholder ethic between enterprises and shareholders: the most basic task is to pursuing benefits; therefore the enterprises must operate positively and pursue more profits to create more rights and interests for shareholders.

Labor-capital ethic between enterprises and employees: how can the labor and the capital trust each other; how can the labor and the capital have a harmonious relationship; ethical leadership and management; education training.

Customer ethic between enterprises and customers: enterprises' survival foundation is to taking meeting customers' demands as their core spirit. Customers are not only the leading role of enterprise management but also the important value of enterprise's existence. 
Competition ethic between enterprises and the same industry: non-price competition (vicious competition), spreading false rumors (poison-pen letter, malicious slander), malignant poaching, theft of trade secrets, etc.

State-business ethic between enterprises and the government: the government's policies need cooperation and support from business circles. Enterprises in the socialist country should obey the law, pay taxes as required, actively respond to the nation's industrial and financial policy, and work as good enterprise citizens.

Social responsibility between enterprises and the society: enterprises and the society are closely bound up. Enterprises can't operate independently if divorce from the society. While seeking to maximize the economic interests of themselves and shareholders, enterprises should fulfill the social responsibility of protecting the environment and be liable for the environmental public interest on behalf of the government.

\section{Basic Situation of Chinese Coal Enterprise Ethic}

\subsection{Imbalance of Game between Life Value and the Economic Benefits}

Since the 21st century, due to the acceleration of economic development, demand for energy is increased and coal price rises quickly, followed by often coal mine accidents which make miners' death toll at an all-time high. Miners are working in the most difficult and the most dangerous environment when they make great contribution and sacrifice for the state and the society, but their lives don't get enough attention that they deserve.

Production safety is the eternal theme in coal mines. Production safety can't do without enough safety investment, and under-investment results in difficulty to guarantee safety in production. During planned economy period, safety measures capital of the state-owned key coal mine was put in by the state, and a fixed sum is for a fixed purpose. At that time, hardware input of production safety is relatively guaranteed. But in the market economy period, coal mine management system has changed, so the state invests no longer, and various fees are borne by the coal mines themselves. Since some state-owned coal enterprises' production efficiency was perennially poor, days and months multiplying, it's impossible to put in for safety and lack of safety input leads to the accidents. Because of the short contract term spending 3 to 5 years, most private coal mine contractors dare not to put in too much capital in case that they can't recover the cost during the contract term. As a result, their approach is less input but more coal. Short-term behaviors of coal mining contractors like random choosing and excessively mining bring huge hidden trouble to production safety. What's more, a few years ago, the penalties for accidents did not reach the designated position, which to some extent also indulge the accidents. Without material conditions to ensure production safety, the miners' lives are threatened at any time.

\subsection{Absence of Ecological Ethic}

Along with rapidly increasing coal production in our country, coal mining and use bring more and more serious impacts to ecological environment, which cause a waste of our country's coal resources and accelerates its drying up, and the environmental pollution is increasingly serious. In part of mining areas in our country, after decades of large-scale mining subsidence, more and more mining area land was damaged. In addition, the coal enterprises' mining causes' solid waste pollution by a large number of earth-rock mixed pile and waste rock, which can occupy a large land area and bring much difficulty to reclamation planting work, what's more, natural plants are difficult to grow again. Both mine water formed in the process of mining and slime water discharged by coal preparation plants can cause serious pollution to the environment. Mine water and coal slime water can easily pollute the river water in mining area and bring a great inconvenience to people's life. Large emission of mine water in the process of mining causes a serious waste of water; there is a large number of suspended solids such as braise, rock powder and so on in coal mine water, which cause serious pollution to the mining area environment. Moreover, coal preparation plants exhaust a mass of coal waste water. Though the coal slime water emission is less than mine water a year, the pollution of coal slime water is more serious. 


\subsection{Lack of Social Responsibility Consciousness}

Coal enterprises generally ignore their social responsibilities. A few small coal mine owners try all to evade taxes and avoid social responsibility. For high profits, some coal mine owners ignore the national laws and regulations and illegally produce in the case of no certificate or incomplete licenses. About labor-capital relationship, some coal enterprise managers don't pay attention to people-oriented prioritization, or even parts of enterprises do not sign labor contracts with employees; their behaviors like withholding, defaulting or lowering wages and sacking employees at will greatly damage the legitimate rights and interests of employees. Labor dispute problems exist not only in private coal enterprises but also in some large-scale state-owned coal enterprises. About enterprise internal management, parts of private coal owners don't respect personality, dignity and rights of employees, and ignore the training to employees, which violates the fundamental humanistic ethic.

\section{Construction of Coal Enterprise Ethic System}

Enterprises are cells of modern society; they are also the main body of market economy. Modern enterprises should have citizen consciousness and improve their own ethical standards. The concept of "corporate citizenship" contains demands to the enterprises suggested by the society, which means that enterprises are citizens of the society and they should bear the responsibilities and obligations to all parties of the society.

Coal in our country occupied above $70 \%$ proportion of one-time energy consumption for a time. Coal mines have important status in the national energy production. The construction goal of harmonious society calls for coal enterprises to build their own ethic system. Harmonious enterprises are important parts of harmonious society. Good enterprise ethic also is advantageous to the enterprises and their stakeholders in maintaining a harmonious relationship and enhancing the enterprises' lasting competitiveness, so it is necessary to strengthen construction of coal enterprise ethic.

\subsection{To Strengthen the State-business Ethic Construction of Coal Enterprises}

Currently in our country all kinds of coal enterprises are more than 10,000, the government will strengthen the efforts to rectification-closure, mergers-reorganization and integration-technological renovation, then the number of coal enterprises will be controlled within 4000, of which will form large-scale coal enterprise groups contains $6 \sim 8$ groups with grade of one hundred million tons and 8 $\sim 10$ groups with grade of 5000 tons. As enterprise citizens, coal mines should be positive to respond national policies, consciously accept the supervision of safety supervision bureau, coal supervision bureau and other departments, increase safety input, and not lie about or conceal the accidents; they should also deliver taxes as required, not make false account, not be shoddy and there should be no commercial bribery, then to define their management behavior within the legal system of market economy.

\subsection{To strengthen the employee ethic construction of coal enterprises}

Employee ethic of coal enterprise is the key point of enterprise ethic. First, set up a core concept of "safety first, people-oriented"; really take care of employees' life value and health value; intent on production safety and rescue in time once the accident occurred. Second, respect for employees, especially the underground miners; cannot take miners as a tool for coal mines or personal wealth; the miners should be regarded as the interests of community relating to enterprises' survival and as precious human resources for coal mines to cherish. Third, create good working and living environment to make the employees work safely, comfortably and dignifiedly. Fourth, improve the labor-capital relationship and protect the lawful rights and interests of workers. Fifth, care for needy workers and give full play to the functions of the trade unions.

\subsection{To Strengthen Ecological Ethic Construction of Coal Enterprises}

Coal mining can inevitably cause damage to the ecological environment, so it is very urgent to strengthen the ecological ethic construction of coal enterprises. First, try to adopt advanced coal mining modes, avoid predatory development and maximize resource utilization. Secondly, prevent and control pollution in time and protect the ecological environment. Formulate the corresponding 
control measures for pollution factors produced in the process of coal mining and use; increase funding investment and science \& technology input to control pollution. Finally, adhere to the circular economy and get the way of sustainable development. Strengthen governance to ecological environment restoration of abandoned coal mines and old coal mines. Come to an end of the extensive growth mode at the cost of sacrificing environment and destroying resources.

\subsection{Raise Social Responsibility Awareness of Coal Enterprises}

Society is the source of enterprise interests. As a social citizen and part of the society, the enterprise must be integrated into the social groups and interact with all kinds of social organizations. The enterprises can win the reputation and social identity by bearing the social responsibility, meanwhile they can reflect their own values better and win better social atmosphere, and thus they can urge the enterprises to develop more smoothly.

\section{Summary}

Coal enterprise ethic is ethic among stakeholders of coal enterprises; to become the driving force for the development of the society, it requires that the ethic of coal enterprises is consistent with the socialist ethical values. In the economic development of our country, the operation tenet of coal enterprise is to paying attention to safety in production, attaching great importance to the miners' life value, strengthening social responsibility of coal enterprises, protecting human survival environment and realizing the harmonious development of enterprise-society and human-nature, and this is the comprehensive way to setting up and implementing scientific development view, and realizing comprehensive and coordinated development of the coal industry.

\section{References}

[1] Gaoyuan Qian. Business ethics. China Textile \& Apparel Press, 2000, p10-25.

[2] Bin Zhang. Motivation, strategy and connotation of enterprise labor relations ethics management. Inquiry into Economic Issues.2010.No. 7, p. 88-92.

[3] Liping Zhang, Xiaofu Wang. Anomie and Its Countermeasures on coal enterprise ethics. Journal of Yichun College. Vol. 31 (2009) No. 12, p. 26-33.

[4] Liping Zhang. Ethical basis of coal enterprise operation. Journal of Jiangxi Finance College. Vol. 22 (2009) No. 6, p.69-70.

[5] Wenyuan Bai, Yunsheng Zhao. Analysis and countermeasures of inadequate investment in coal mining enterprise security. Labour Protection.2005.4, p. 90-91.

[6] Yasha Yuan. Generation and construction of corporate ethics in the marketization process of China. Reform of Economic System2008.3, p. 67-71. 